\title{
Multi-Group Analysis Innovation Diffusion dan Technology Acceptance Factors Terhadap Niat Mengadopsi Wearable Technology dengan Gender sebagai Moderator
}

\author{
Deatri Arumsari Agung \\ Universitas Katolik Widya Mandala Surabaya \\ Lydia Ari Widyarini \\ Universitas Katolik Widya Mandala Surabaya \\ *lydiaari@ukwms.ac.id
}

\begin{abstract}
Abstrak
Wearable technology adalah teknologi yang dikenakan oleh penggunanya dan dilengkapi dengan sensor untuk menangkap data sehingga dapat diolah dan disajikan menjadi infomasi yang bermanfaat bagi penggunanya. Kajian tentang adopsi masyarakat terhadap wearable device ini perlu dilakukan untuk menyusun strategi dalam mempercepat adoption rate di masyarakat. Adopsi pada inovasi dan teknologi ini dikaji dengan Technology Acceptance Model (Davis 1986) dan Innovation Diffusion Theory (Rogers 1983). Bagaimana variabel compatibilty, visibility, image, result demonstrability, dan voluntariness, serta variabel perceived ease of use dan perceived usefulness, terhadap variabel adoption intention perlu dikaji lebih dalam. Kuesioner disebar pada 218 responden dan dianalisis menggunakan structural equation model (SEM). Hasil penelitian menunjukkan bahwa compatibility memiliki peran dominan terhadap perceived usefulness, diikuti result demonstrability, visibility, image dan voluntariness. Variabel perceived ease of use tidak memiliki pengaruh terhadap perceived usefulness, namun berpengaruh langsung terhadap niat seseorang untuk menggunakan wearable technology. Gender tidak memoderasi pengaruh variabel perceived ease of use dan perceived usefulness terhadap niat seseorang untuk mengadopsi wearable technology. Pengembang dan peritel produk wearable technology dapat mengetahui bahwa motivasi seseorang dalam mengadopsi teknologi tersebut dipengaruhi secara langsung oleh faktor perceived ease of use dan perceived usefulness, serta secara tidak langsung oleh faktor compatibility, result demonstrability, visibility, image, dan voluntariness.
\end{abstract}

Kata Kunci: wearable technology, innovation difusion theory, technology acceptance model

\section{Pendahuluan}

Evolusi teknologi seperti komputer dan smartphone membawa perubahan dramatis pada gaya hidup masyarakat. Munculnya wearable technology, misalnya self-driving cars dan drones merupakan beberapa parameter bahwa masyarakat telah memasuki era Internet of Things. Wearable technology tidak bisa dipisahkan dari Internet of Things (IoT), keduanya harus berinteraksi secara berdampingan dengan cloud system dan aplikasi big data (Pricewaterhouse Coopers 2014).

Penelitian beberapa tahun ini, mendefinisikan wearable technology sebagai peralatan elektronik dengan berbagai bentuk (Liu et al. 2016) yang dipakai secara langsung pada tubuh sebagai aksesoris dan memiliki kapabilitas komputerisasi (Nunes \& Filho 2018), serta memiliki fitur tertentu seperti fungsi komunikasi dalam bentuk mengirim pesan serta kapasitas data- 
mining otomatis melalui prosesor biometrik (Park \& Skoric 2017). Wearable technology menjadi viral, diiringi dengan spekulasi dan sikap skeptis masyarakat, apakah inovasi ini akan membawa dampak positif atau negatif bagi pengguna.

Nilai pasar global wearable technology mencapai USD 32,63 miliar pada 2019 (Grand View Research 2020). Fitness bands seperti Jawbone, Fitbit, dan Goodon, alat untuk memonitor kondisi kesehatan di manapun pengguna berada; smart watches seperti Geak Watch, iWatch, dan Samsung Galaxy Gear, jam tangan yang memiliki fungsi-fungsi standar smartphone; headset nirkabel yang memungkinkan pengguna untuk mendengarkan musik via bluetooth, dan Google glass, kacamata yang mampu mengambil video atau foto dan memproyeksikan informasi dari internet pada layar kacamata; adalah jenis-jenis wearable technology yang sudah ramai di pasaran. Namun masih banyak produk lain yang belum dipasarkan secara optimum dan tidak begitu menarik perhatian masyarakat khususnya di Indonesia. Salah satu asumsi penyebabnya yaitu fungsi yang tidak sesuai ekspektasi, tidak menutup kemungkinan harga juga menjadi pertimbangan penting, namun masih banyak faktor lain yang belum teridentifikasi dengan jelas, apa sajakah yang mempengaruhi niat calon pengguna untuk mengadopsi produk-produk wearable technology.

Dalam konteks pekerjaan, wearable technology dapat digunakan sebagai alat untuk melatih karyawan, mempercepat proses yang sedang berlangsung melalui feedback yang tepat waktu. Dalam konteks ritel, wearable technology dapat memangkas proses point of sale, meningkatkan customer service di seluruh toko, dan mempercepat pembelian. Dalam konteks manufaktur, wearable technology dapat mempercepat proses produksi dengan menciptakan alat pandu yang hands-free. Dalam konteks industri jasa, wearable technology dapat mempercepat akses informasi secara tepat waktu dan memungkinkan terjadinya rangkaian aktivitas yang tidak terputus. Dalam konteks pusat kesehatan, wearable technology dapat meningkatkan akurasi informasi, merampingkan prosedur dan meningkatkan uji klinis. Serta dalam konteks fitness, wearable technology dapat mengarah pada penurunan biaya kesehatan yang signifikan (Pricewaterhouse Coopers 2014).

Pricewaterhouse Coopers (2014) menyatakan bahwa early adoption rate cukup konsisten antara laki-laki dan perempuan, namun laki-laki cenderung lebih vokal dalam menyikapi wearable technology. Hal ini terlihat dari percakapan di Twitter di mana $71 \%$ pembahasan wearable technology didominasi oleh laki-laki. Dalam konteks wearable technology, early adopters mencakup $21 \%$ populasi di Amerika yang memiliki karakteristik paham teknologi dan lebih berpendidikan. Secara keseluruhan, laporan tersebut menyatakan adanya kebutuhan yang ingin dipenuhi oleh masyarakat melalui adopsi wearable technology yaitu mengurangi stres, mendorong perilaku yang mengarah pada pencapaian tujuan, menguatkan hubungan dengan keluarga dan teman-teman, membantu untuk memiliki waktu luang lebih, dan peningkatan customer service (Pricewaterhouse Coopers 2014).

Tantangan yang dihadapi produsen wearable technology memiliki titik berat pada strategi dalam mempercepat adoption rate di masyarakat. Beberapa teori yang paling populer dalam mempelajari pengadopsian inovasi dan teknologi adalah Technology Acceptance Model (Davis 1986) dan Innovation Diffusion Theory (Rogers 1983). Kedua teori telah dikembangkan selama beberapa dekade mengikuti perkembangan fenomena perilaku konsumen, khususnya di bidang inovasi dan teknologi. Seiring perkembangannya, TAM dan IDT yang telah diperbarui, digunakan sebagai model framework untuk meneliti niat calon pengguna dalam mengadopsi sebuah inovasi atau teknologi, sebelum mengarah pada penggunaan inovasi atau teknologi tersebut. Teori TAM yang digunakan pada penelitian ini mengacu pada teori yang diperkenalkan oleh Davis (1986), di mana niat mengadopsi sebuah teknologi ditentukan oleh perceived ease of use dan perceived usefulness. Model IDT yang digunakan pada penelitian ini mengacu pada pengembangan yang dilakukan oleh Moore \& Benbasat (1991), di mana niat 
mengadopsi sebuah teknologi dapat dipengaruhi oleh relative advantage, compatibility, visibility, image, result demonstrability, voluntariness, dan ease of use. Tidak seperti TAM, model IDT oleh Moore \& Benbasat belum terlalu banyak digunakan dalam penelitianpenelitian sebelumnya. Oleh sebab itu pada penelitian ini akan digunakan integrasi model TAM original dan IDT versi Moore \& Benbasat, dikarenakan kombinasi keduanya dapat mengarah pada pengembangan sebuah model yang holistik untuk menjelaskan variabel-variabel yang mempengaruhi terbentuknya niat individu dalam mengadopsi suatu teknologi (Hubert et al. 2019).

Penelitian ini dilakukan untuk menentukan faktor apa saja yang mempengaruhi terbentuknya niat masyarakat Indonesia, dalam mengadopsi wearable technology untuk pertama kalinya. Faktor apa saja yang akan menentukan seberapa cepat fase penyebaran awal teknologi akan masuk ke fase growing market, dalam proses difusi atau penyebaran wearable technology. Penelitian ini juga bertujuan memberikan benefit bagi pengembang dan peritel wearable technology berupa customer insight untuk mempercepat laju proses penyebaran. Pada penelitian ini akan diuji pengaruh compatibilty, visibility, image, result demonstrability, voluntariness, dan perceived ease of use terhadap perceived usefulness dari wearable technology; serta pengaruh perceived ease of use dan perceived usefulness terhadap niat individu untuk mengadopsi wearable technology.

\section{Landasan Teori dan Pengembangan Hipotesis}

\section{Innovation Diffusion Theory (IDT)}

Rogers (1983) dalam bukunya menjelaskan bagaimana Innovation Diffusion Theory (IDT) menerangkan faktor-faktor yang mempengaruhi seseorang dalam mengadopsi inovasi. Rogers mengidentifikasi lima karakteristik sebagai anteseden dalam keputusan mengadopsi sebuah inovasi: relative advantage, compatibility, complexity, trialability, dan observability. IDT dikembangkan oleh Moore \& Benbasat (1991) menjadi sebuah model yang terdiri dari tujuh variable: relative advantage, compatibility, visibility, image, result demonstrability, voluntariness, dan ease of use. Model IDT yang sudah dikembangkan tersebut bertujuan mempelajari proses adopsi awal suatu sistem informasi dan teknologi oleh individu.

Compatibility menunjukkan sejauh mana inovasi dianggap konsisten dengan nilai, kebutuhan, dan pengalaman masa lalu dari calon pengguna. Pada calon pengguna, sebuah ide yang lebih kompatibel akan memiliki ketidakpastian yang lebih rendah (Rogers 1983). Compatibility yang lebih besar mengarah pada tingkat adopsi yang lebih cepat, hal ini menjelaskan dampaknya yang kuat terhadap niat seseorang mengadopsi teknologi (Hubert et al. 2019).

Visibility menunjukkan sejauh mana inovasi dapat terlihat di dalam suatu organisasi (Rogers 1983). Dengan kata lain, visibility didefinisikan sebagai sejauh mana sebuah inovasi terekspos pada publik (Wani \& Ali 2015). Mendukung definisi Rogers, visibility menujukkan sejauh mana orang lain dapat melihat bahwa sebuah inovasi sedang digunakan (Benham \& Raymond 1996). Visibility terbukti memiliki pengaruh yang instrumental dalam meyakinkan calon pengguna (Agarwal \& Prasad 1997).

Image menunjukkan sejauh mana penggunaan sebuah inovasi dapat meningkatkan citra atau status seseorang (Rogers 1983). Rogers berpendapat bahwa image merupakan aspek dari relative advantage, namun memiliki efek yang cukup berbeda (Moore \& Benbasat 1991). Dalam penelitian Venkatesh \& Davis (2000), image dikategorikan sebagai salah satu aspek 
proses pengaruh sosial. Meningkatnya status sosial seseorang dipercaya sebagai basis untuk produktivitas yang lebih tinggi.

Result demonstrability menunjukkan sejauh mana hasil penggunaan sebuah teknologi sistem informasi dapat diobservasi dan dikomunikasikan kepada orang lain (Rogers 1983). Menurut Wani \& Ali (2015), result demonstrability adalah tangibility dari hasil menggunakan sebuah inovasi. Result demonstrability menjadi salah satu dimensi dari observability (Moore \& Benbasat 1991), dan memiliki pengaruh yang signifikan terhadap perceived ease of use (Venkatesh \& Davis 2000).

Voluntariness menunjukkan sejauh mana penggunaan inovasi secara sukarela dan bukan karena paksaan (Moore \& Benbasat 1991). Moore \& Benbasat berpendapat bahwa perceived voluntariness berpengaruh terhadap niat. Dalam mempelajari proses difusi sebuah inovasi, harus mempertimbangkan kebebasan seseorang dalam memilih untuk mengimplementasi atau menolak. Pada TAM2, voluntariness termasuk salah satu aspek proses pengaruh sosial (Venkatesh \& Davis 2000).

\section{Technology Acceptance Model (TAM)}

Technology Acceptance Model (TAM) diperkenalkan oleh Davis di tahun 1986, menjadi sebuah konsep user acceptance yang kuat dan populer dalam komunitas sistem informasi. Konsep TAM terus dikembangkan dan diaplikasikan pada bermacam spesifikasi teknologi, dalam berbagai situasi, dengan faktor pengendali dan subjek yang berbeda-beda (Lee et al. 2003; Mutahar et al. 2017). TAM diadopsi dari sebuah teori yang dikemukakan oleh Fishbein \& Ajzen pada tahun 1975 yaitu Theory of Reasoned Action (TRA). Konstruk inti TAM adalah dua persepsi utama dari pengguna atau calon pengguna yaitu perceived usefulness dan perceived ease of use. Kedua persepsi tersebut mempengaruhi behavioural intention, yang akan menentukan actual use.

Perceived usefulness menunjukkan sejauh mana seseorang percaya bahwa menggunakan suatu sistem tertentu dapat meningkatkan kinerja. Calon pengguna terdorong mengadopsi aplikasi terutama dikarenakan fungsi yang mereka dapatkan (Davis 1989). Menurut penelitian Moore \& Benbasat (1991), perceived usefulness memiliki karakteristik yang sama dengan relative advantage pada IDT. Oleh karena itu relative advantage tidak dimasukkan ke dalam model penelitan ini.

Perceived ease of use menunjukkan sejauh mana seseorang percaya bahwa dalam menggunakan suatu sistem tertentu akan bebas dari upaya fisik dan mental (Davis 1989). Sebuah sistem yang mudah digunakan akan berdampak pada kinerja yang meningkat. Maka perceived ease of use secara teori memiliki efek langsung terhadap perceived usefulness (Davis 1989). Menurut penelitian Davis, calon pengguna terdorong untuk mengadopsi sebuah aplikasi selain dikarenakan fungsi yang mereka dapatkan, juga seberapa mudah mengoperasikan sistem tersebut.

Intention didefinisikan sebagai niat atau motif yang dimiliki seseorang ketika mencoba perilaku tertentu. Menurut Theory of Planned Behaviour (Ajzen 1991), ini adalah faktor yang paling menentukan secara langsung ketika seseorang mencoba perilaku tertentu. Intention diasumsikan dapat menangkap faktor-faktor motivasi yang mempengaruhi perilaku, yaitu indikasi yang menunjukkan sejauh mana seseorang mau mencoba, atau seberapa banyak usaha yang mau dilakukan, untuk dapat berperilaku tertentu (Ajzen 1991). 


\section{Pengaruh Compatibility terhadap Perceived Usefulness}

Hubert et al. (2019) dalam penelitiannya menyatakan bahwa compatibility memiliki pengaruh yang kuat dan positif terhadap perceived usefulness. Hal ini menunjukkan bahwa pengguna menginginkan teknologi yang memfasilitasi dan meningkatkan kehidupan mereka, tanpa menyebabkan perubahan yang signifikan terhadap gaya hidup dan lingkungan mereka. Kesimpulan yang sama diperoleh dari penelitian Wang \& Lin (2016), di mana compatibility merefleksikan persepsi seseorang tentang keterkaitan sebuah inovasi dengan perilaku dan preferensi yang dimiliki. Compatibility juga terbukti memiliki pengaruh langsung yang signifikan terhadap perceived usefulness dalam penelitian Chau \& Hu (2001; dalam Lee et al. 2011). Maka dapat diasosiasikan ke dalam penelitian ini bahwa jika wearable technology memiliki kesesuaian dan konsistensi dengan kebutuhan dan gaya bekerja, maka masyarakat akan semakin percaya bahwa menggunakan wearable technology akan meningkatkan produktivitas dalam pekerjaan maupun dalam aktivitas sehari-hari. Berdasarkan argumen teoritis tersebut maka dirumuskan hipotesis yang akan diuji sebagai berikut.

H1: Diduga compatibility berpengaruh terhadap perceived usefulness dari wearable technology.

\section{Pengaruh Visibility terhadap Perceived Usefulness}

Dalam penelitiannya, Rogers (2003) menjelaskan bahwa visibility sebuah inovasi dapat meningkatkan kemungkinan calon pengguna untuk mengadopsi. Penelitian yang mendukung kombinasi teori TAM \& IDT pada berbagai bidang membuktikan bahwa semakin tinggi tingkat visibility maka semakin tinggi perceived usefulness yang dirasakan oleh calon pengguna (Huang 2004; Yang 2007; dalam Lee et al. 2011). Maka, dapat diasosiasikan ke dalam penelitian ini bahwa jika penggunaan wearable technology dapat dengan mudah dilihat dan diamati, maka masyarakat akan semakin percaya bahwa menggunakan wearable technology akan meningkatkan produktivitas dalam pekerjaan maupun dalam aktivitas sehari-hari. Berdasarkan argumen teoritis tersebut maka dirumuskan hipotesis yang akan diuji sebagai berikut.

H2: Diduga visibility berpengaruh terhadap perceived usefulness dari wearable technology.

\section{Pengaruh Image terhadap Perceived Usefulness}

Venkatesh \& Davis (2000) menyimpulkan dari penelitiannya bahwa image memiliki pengaruh yang signifikan terhadap perceived usefulness. Seseorang dapat memiliki persepsi bahwa menggunakan suatu teknologi akan mengarah pada peningkatan kinerja, atau dengan kata lain peningkatan perceived usefulness. Dapat diasosiasikan ke dalam penelitian ini bahwa jika penggunaan wearable technology dianggap meningkatkan citra atau status seseorang dalam sistem sosial, maka masyarakat akan semakin percaya bahwa menggunakan wearable technology akan meningkatkan produktivitas dalam pekerjaan maupun dalam aktivitas seharihari. Berdasarkan argumen teoritis tersebut maka dirumuskan hipotesis yang akan diuji sebagai berikut.

H3: Diduga image berpengaruh terhadap perceived usefulness dari wearable technology. 
INOBIS: Jurnal Inovasi Bisnis dan Manajemen Indonesia

Volume 04, Nomor 02, Maret 2021

Deatri Arumsari Agung, Lydia Ari Widyarini

\section{Pengaruh Result Demonstrability terhadap Perceived Usefulness}

Beberapa penelitian terdahulu (Venkatesh \& Davis 2000; Hubert et al. 2019) menunjukkan bahwa, result demonstrability memiliki pengaruh yang signifikan terhadap perceived usefulness. Dalam penelitiannya, Hubert et al. (2019) menemukan bahwa kemampuan untuk mengkomunikasikan nilai teknologi menyebabkan perceived usefulness yang lebih baik. Maka, dapat diasosiasikan ke dalam penelitian ini bahwa jika hasil dari menggunakan wearable technology dapat terlihat dan dikomunikasikan kepada orang lain dengan mudah, maka masyarakat akan semakin percaya bahwa menggunakan wearable technology akan meningkatkan produktivitas dalam pekerjaan maupun dalam aktivitas seharihari. Berdasarkan argumen teoritis tersebut maka dirumuskan hipotesis yang akan diuji sebagai berikut.

H4: Diduga result demonstrability berpengaruh terhadap perceived usefulness dari wearable technology.

\section{Pengaruh Voluntariness terhadap Perceived Usefulness}

Venkatesh \& Davis (2000) merumuskan pada model TAM2 bahwa voluntariness adalah elemen dari pengaruh sosial dan memiliki dampak terhadap perceived usefulness. Model tersebut diperkaya oleh Venkatesh et al. (2008; dalam Hassani et al. 2017) menjadi TAM3, dengan tetap memasukkan voluntariness sebagai elemen pengaruh sosial yang mempengaruhi perceived usefulness. Maka dapat diasosiasikan ke dalam penelitian ini bahwa jika penggunaan wearable technology dianggap sukarela atau melalui kehendak bebas seseorang, maka masyarakat akan semakin percaya bahwa menggunakan wearable technology akan meningkatkan produktivitas dalam pekerjaan maupun dalam aktivitas sehari-hari. Berdasarkan argumen teoritis tersebut maka dirumuskan hipotesis yang akan diuji sebagai berikut.

H5: Diduga voluntariness berpengaruh terhadap perceived usefulnes dari wearable technology.

\section{Pengaruh Perceived Ease of Use, Perceived Usefulness, dan Adoption Intention}

Secara konseptual, perceived usefulness dan perceived ease of use memiliki pengaruh terhadap adoption intention. Teori TAM (Davis 1989) merumuskan bahwa ketika sebuah inovasi baru diperkenalkan kepada calon pengguna, faktor utama yang mempengaruhi keputusan untuk mengadopsi teknologi tersebut termasuk perceived usefulness dan perceived ease of use. Pengguna akan terdorong untuk mengadopsi sebuah teknologi, yang pertama dikarenakan fungsi yang didapatkan, dan yang kedua dikarenakan tingkat kemudahan dalam mengoperasikan teknologi tersebut. Perceived usefulness adalah faktor penentu niat yang utama sedangkan perceived ease of use adalah faktor penentu terkuat kedua (Venkatesh \& Davis 2000). Bukti empiris telah terakumulasi lebih dari satu dekade bahwa perceived ease of use secara signifikan mempengaruhi niat, baik secara langsung, maupun secara tidak langsung melalui perceived usefulness (Davis et al. 1989; Venkatesh 1999 dalam Venkatesh \& Davis 2000). Maka dapat diasosiasikan ke dalam penelitian ini bahwa jika wearable technology dianggap mudah untuk digunakan, maka masyarakat akan semakin percaya bahwa menggunakan wearable technology akan meningkatkan produktivitas dalam pekerjaan maupun dalam aktivitas sehari-hari. Di sisi lain, jika wearable technology dianggap mudah untuk digunakan, maka secara langsung akan berdampak pada niat yang lebih kuat dalam mengadopsi 
atau menggunakan wearable technology. Berdasarkan argumen teoritis tersebut maka dirumuskan hipotesis yang akan diuji sebagai berikut.

H6: Diduga perceived ease of use berpengaruh terhadap perceived usefulness dari wearable technology.

H7: Diduga perceived ease of use berpengaruh terhadap adoption intention dari wearable technology.

H8: Diduga perceived usefulness berpengaruh terhadap adoption intention dari wearable technology.

Model penelitian dapat dilihat pada Gambar 1 sebagai berikut:

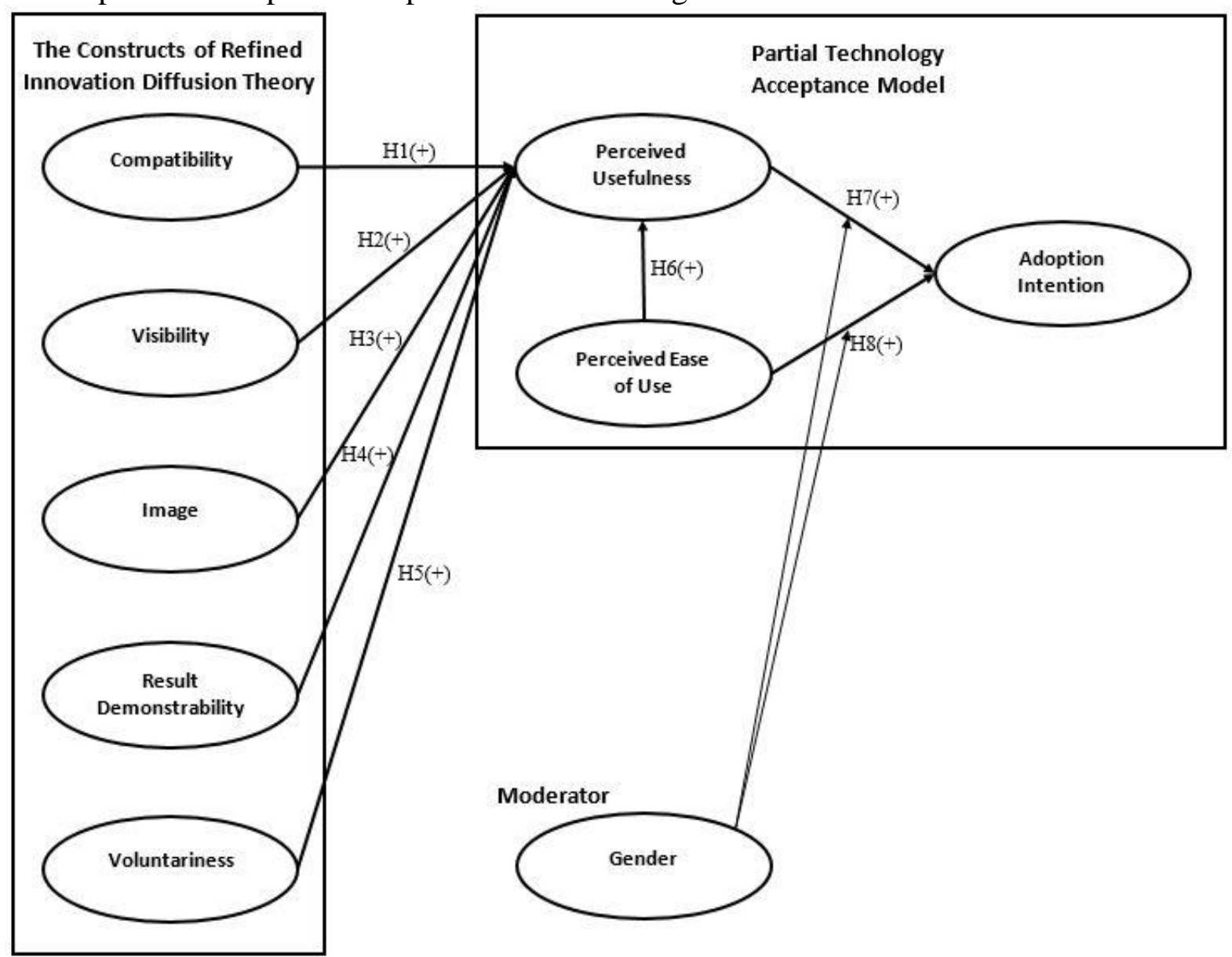

Gambar 1. Model Penelitian (referensi: data diolah)

\section{Metode Penelitian}

Sesuai dengan tujuan penelitian, IDT dan TAM diintegrasikan untuk menganalisis pengaruh mana yang paling signifikan terhadap niat masyarakat untuk mengadopsi wearable technology, dengan ditambahlan faktor gender sebagai pemoderasi yang dapat memperkuat atau melemahkan pengaruh masing-masing faktor tersebut. Penelitian ini didesain dalam bentuk causal research dengan ruang lingkup strategi pemasaran yang berkaitan dengan strategi komunikasi pemasaran dan perilaku adopsi teknologi oleh masyarakat Indonesia khususnya terhadap wearable technology. Obyek penelitian yang merupakan variabel eksogen adalah lima variabel dari pengembangan Innovation and Diffusion Theory yaitu compatiblty, 
visibility, image, result demonstrability, voluntariness, dan variabel technology acceptance model yaitu perceived ease of use. Variabel endogen yang bertindak sebagai mediator adalah perceived usefulness, sedangkan variabel endogen akhir yang dipengaruhi yaitu adoption intention. Penelitian ini juga memasukkan variabel gender yang bertindak sebagai moderator.

Definisi operasional yang digunakan dalam penelitian ini diadopsi dari Technology Acceptance Model (Davis 1989) dan Innovation Diffusion Theory (Roger 1983). Compatibility adalah sejauh mana wearable technology dianggap konsisten dengan kebutuhan saat ini maupun pengalaman masa lalu dalam konteks pekerjaan. Visibility adalah semudah apa orang dapat melihat orang lain menggunakan wearable technology. Image adalah sejauh mana penggunaan wearable technology dianggap meningkatkan citra atau status seseorang dalam sistem sosial. Results demonstrability adalah semudah apa hasil dari menggunakan wearable technology dapat terlihat dan dikomunikasikan. Voluntariness adalah sejauh mana penggunaan wearable technology bersifat sukarela atau melalui kehendak bebas. Perceived ease of use adalah sejauh mana wearable technology dianggap mudah untuk digunakan. Perceived usefulness adalah sejauh mana seseorang percaya bahwa menggunakan wearable technology akan meningkatkan kinerjanya. Adoption intention adalah niat sebagai probabilitas subjektif dan dorongan yang dimiliki seseorang untuk menggunakan atau melakukan pembelian terhadap wearable technology.

Populasi pada penelitian ini adalah seluruh pengguna internet di Indonesia. Subyek penelitian ini adalah pengguna internet di Indonesia yang belum pernah menggunakan wearable technology. Penentuan responden menggunakan teknik purposive sampling. Dalam penelitian ini, besarnya sampel disesuaikan dengan model analisis yang digunakan yaitu Structural Equation Modelling (SEM). Jumlah responden adalah sebesar 218 responden. Karakteristik responden yang dijadikan sampel adalah warga Indonesia pengguna internet yang mengetahui wearable technology tetapi belum pernah menggunakannya.

Instrumen utama yang digunakan untuk mengumpulkan data primer dalam penelitian ini adalah kuesioner. Pengukuran variabel dilakukan dengan menggunakan skala Likert, sedangkan data diolah menggunakan SmartPLS 3.0.

\section{Pembahasan}

Responden berjenis kelamin laki-laki adalah sebanyak 34,6\% dan $65,4 \%$ berjenis kelamin perempuan. Penyebaran responden berusia di antara 17-30 tahun sebanyak 70,5\%, di antara 31-40 tahun sebanyak 5,4\% di antara 41-50 tahun sebanyak 17,5\%, dan yang lebih dari 50 tahun sebanyak $6,7 \%$. Tingkat pendidikan responden menunjukkan penyebaran mulai dari SMA, D3, S1, S2 dan S3, dengan proporsi yang paling banyak SMA $(54,2 \%)$ dan S1 $(32,1 \%)$ atau total $86,3 \%$ dari jumlah responden. Maka perilaku mereka yang merupakan konsumen potensial untuk mengadopsi waerable technology dapat digunakan sebagai acuan.

Reliabilitas variabel dari nilai akar composite reliability, menunjukkan nilai lebih besar dari 0,7 maka dikatakan bahwa semua konstruk memenuhi kriteria composite reliability, demikian juga nilai cronbach alpha juga lebih dari 0,7. Menurut Hair et al. (2014) convergen validity juga dilihat dari besarnya outer loading. Validitas indikator individu dianggap reliable jika memiliki nilai korelasi tinggi yaitu di atas 0,70. Namun demikian pada riset tahap pengembangan skala loading factor 0,50 sampai 0,60 masih dapat diterima (Chin 1988 dalam Ghozali \& Latan 2015). Berdasarkan hasil pengukuran convergent validity, semua koefisien outer loading berada di atas 0,5, maka dapat dijelaskan bahwa semua indikator memenuhi convergent validity. Kriteria lain untuk menilai validitas konvergen adalah dengan melihat Average Variance Extracted (AVE), di mana nilai AVE harus > 0,5 (Hair et al. 2014). Hasil 
pengukuran validitas konvergen menunjukkan semua nilai AVE adalah $>0,5$, sehingga dapat dikatakan bawa semua variabel memenuhi validitas konvergen.

Menurut Hair et al. (2014), untuk mengevaluasi discriminant validity indikator, pertama diuji dari cross loading dan yang kedua dari Foenell-Larcher Criterion. Dari hasil pengujian, besarnya cross loading korelasi konstruk compatibility dengan indikatornya mempunyai nilai lebih tinggi dibandingkan korelasi konstruk compatibility dengan indikator dari konstruk yang lain, dimana hal ini berlaku untuk konstruk yang lain. Kondisi ini menunjukkan bahwa konstruk laten memprediksi indikator pada blok mereka lebih baik dibandingkan dengan indikator dari blok lainnya. Metode lain yang digunakan untuk menilai discriminant validity adalah dengan membandingkan akar kuadrat dari Average Variance Extracted untuk setiap konstruk dengan korelasi antara konstruk dengan konstruk lainnya dalam model. Model memiliki discriminant validity yang cukup jika akar AVE untuk setiap konstruk lebih besar daripada korelasi antara konstruk dengan konstruk lainnya.

Diagonal adalah nilai akar kuadrat AVE dan nilainya lebih tinggi dibandingkan korelasi antar konstruk. Jika nilai akar kuadrat AVE lebih tinggi dari nilai korelasi dengan variabel lain, maka dapat dikatakan bahwa model valid karena memenuhi discriminant validity. Kuadrat AVE pada compatibility sebesar 0,855 lebih besar dibandingkan besarnya koefisien korelasi dari Fornell-Larcker Criterion yang menunjukkan korelasi antara compatibility terhadap image yaitu 0,786 , demikian juga untuk variabel yang lain. Hal ini berarti model dapat dikatakan valid karena memenuhi discrimant validity.

Model pengukuran yang dikenal dengan istilah outer model, pengujian model yang menjelaskan hubungan antar variabel dan pengujian indikator pembentuk konstruk. Nilai outer loading menunjukkan bobot dari setiap indikator sebagai pengukur dari masing-masing variabel laten. Indikator outer loading terbesar menunjukkan bahwa indikator tersebut merupakan pengukur terkuat (dominan). Hasil pengolahan data menggunakan Smart PLS 3 dapat dilihat pada Gambar 2 berikut:

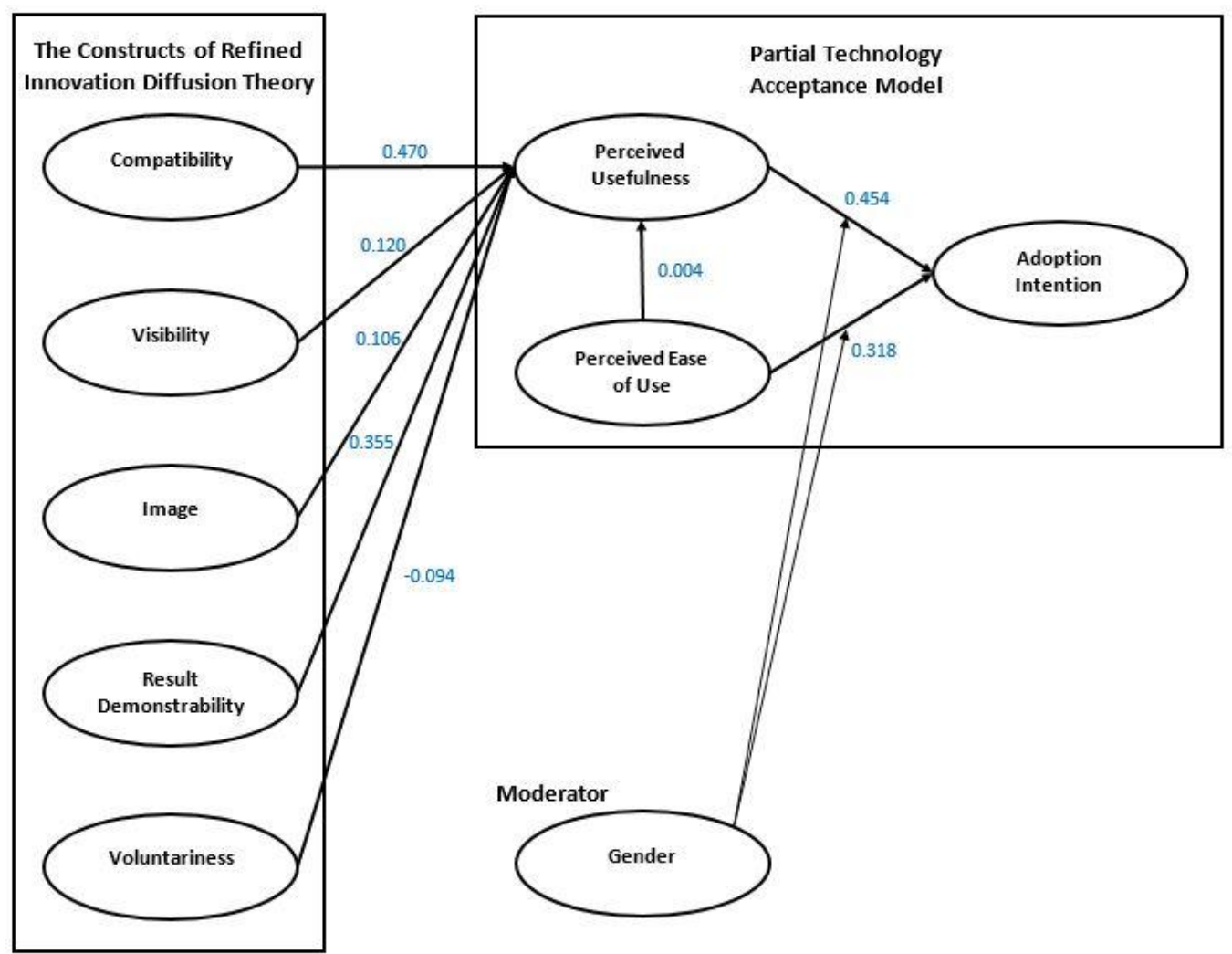

Gambar 2. Model Struktural dengan Koefisien Estimate (referensi: data diolah) 
Evaluasi Collinearity dilihat dari nilai VIF antar variabel laten predictor, hasil pengujian menunjukkan nilai VIF antar variabel laten predictor lebih tinggi dari 0,2 dan lebih rendah dari 5, maka dapat dikatakan bahwa collinearity tidak terjadi pada model struktural yang dikembangkan, maka tidak perlu dilakukan modifikasi model, sehingga evaluasi model struktural dapat dilanjutkan ke langkah berikutnya yaitu mengetahui signifikansi koefisien jalur, kemampuan variabel prediktor untuk menjelaskan perubahan pada variabel endogen yaitu evaluasi relevansi prediktif (Q2).

Nilai $\mathrm{Q}^{2}$ Stone-Geisser merupakan kriteria yang digunakan untuk menilai akurasi prediksi selain nilai $\mathrm{R}^{2}$. Ukuran ini merupakan indikator dari relevansi prediksi model. Nilai $\mathrm{Q}^{2}$ diperoleh dengan prosedur kalkulasi blindfolding untuk mendapatkan pengukuran cross validated redundancy untuk setiap konstruk endogen. Hasil pengujian menunjukkan bahwa nilai $\mathrm{Q}^{2}$ lebih besar dari 0, maka dapat dikatakan bahwa variabel eksogen memiliki predictive relevance tinggi terhadap variabel endogen.

Ukuran pengaruh $\left(\mathrm{f}^{2}\right)$ dapat digunakan untuk mengetahui kekuatan pengaruh variabel laten eksogen terhadap varaiabel endogen pada model. Hasil pengujian menunjukkan bahwa kontribusi (efek) yang dimiliki variabel eksogen compatibility terhadap perceived usefulness adalah sedang. Sedangkan kontribusi variabel eksogen lain yaitu image, perceived ease of use, result demonstrability, visibility, dan voluntariness terhadap perceived usefulness adalah kecil. Kontribusi variabel eksogen perceived ease of use dan perceived usefulness terhadap adoption intention adalah sedang.

Pada Tabel 1, hubungan antar variabel dijelaskan dari besarnya koefisien jalur yang diperoleh setelah proses path coefficient bootstrapping sebagai berikut:

Tabel 1. Hasil Pengujian Hipotesis Inner Model

(Pengaruh Antarvariabel Hasil Pengolahan Bootstrapping)

\begin{tabular}{|c|l|r|r|r|r|}
\hline \multicolumn{7}{|c|}{ Direct Effect } \\
\hline Hipotesis & Hubungan antar Variable & Koefisien & t-statistics & $\begin{array}{c}\text { P } \\
\text { Values }\end{array}$ & Keterangan \\
\hline H1 & $\begin{array}{l}\text { compatibility -> perceived } \\
\text { usefulness }\end{array}$ & 0,470 & 5,475 & 0,000 & Hipotesis Diterima \\
\hline H2 & $\begin{array}{l}\text { visibility -> perceived } \\
\text { usefulness }\end{array}$ & 0,120 & 2,464 & 0,014 & Hipotesis Diterima \\
\hline H3 & $\begin{array}{l}\text { image -> perceived } \\
\text { usefulness }\end{array}$ & 0,106 & 2,407 & 0,016 & Hipotesis Diterima \\
\hline H4 & $\begin{array}{l}\text { resultdemonstrability -> } \\
\text { perceived usefulness }\end{array}$ & 0,355 & 3,740 & 0,000 & Hipotesis Diterima \\
\hline H5 & $\begin{array}{l}\text { voluntariness -> perceived } \\
\text { usefulness }\end{array}$ & $-0,094$ & 2,319 & 0,021 & Hipotesis Diterima \\
\hline H6 & $\begin{array}{l}\text { ease of use -> perceived } \\
\text { usefulness }\end{array}$ & 0,004 & 0,102 & 0,919 & Hipotesis Ditolak \\
\hline H7 & $\begin{array}{l}\text { perceived usefulness -> } \\
\text { adoption intention }\end{array}$ & 0,454 & 7,689 & 0,000 & Hipotesis Diterima \\
\hline H8 & $\begin{array}{l}\text { ease of use -> adoption } \\
\text { intention }\end{array}$ & 0,318 & 5,232 & 0,000 & Hipotesis Diterima \\
\hline Hipotesis & $\begin{array}{l}\text { Hubungan antar Variable } \\
\text { Intention }\end{array}$ & Koefisien & t-statistics & $\begin{array}{l}\text { P } \\
\text { Values }\end{array}$ & \multicolumn{2}{|c|}{ Keterangan } \\
\hline
\end{tabular}


INOBIS: Jurnal Inovasi Bisnis dan Manajemen Indonesia Volume 04, Nomor 02, Maret 2021

Deatri Arumsari Agung, Lydia Ari Widyarini

\begin{tabular}{|l|l|r|r|r|l|}
\hline & $\begin{array}{l}\text { image -> adoption } \\
\text { intention }\end{array}$ & 0,048 & 2,331 & 0,020 & $\begin{array}{l}\text { (perceived usefulness } \\
\text { signifikan sebagai } \\
\text { mediator }\end{array}$ \\
\hline $\begin{array}{l}\text { ease of use -> adoption } \\
\text { intention }\end{array}$ & 0,002 & 0,105 & 0,917 & $\begin{array}{l}\text { (perceived usefulness tidak } \\
\text { signifikan sebagai } \\
\text { mediator }\end{array}$ \\
\hline $\begin{array}{l}\text { resultdemonstrability -> } \\
\text { adoption intention }\end{array}$ & 0,161 & 3,250 & 0,001 & $\begin{array}{l}\text { (perceived usefulness } \\
\text { signifikan sebagai } \\
\text { mediator }\end{array}$ \\
\hline $\begin{array}{l}\text { visibility -> adoption } \\
\text { intention }\end{array}$ & 0,054 & 2,530 & 0,012 & $\begin{array}{l}\text { (perceived usefulness } \\
\text { signifikan sebagai } \\
\text { mediator }\end{array}$ \\
\hline $\begin{array}{l}\text { voluntariness -> adoption } \\
\text { intention }\end{array}$ & $-0,043$ & 2,234 & 0,026 & $\begin{array}{l}\text { (perceived usefulness } \\
\text { signifikan sebagai } \\
\text { mediator }\end{array}$ \\
\hline
\end{tabular}

(referensi: data diolah)

Terdapat 8 (delapan) pengujian hipotesis pengaruh antar variabel maupun efek mediasi yang diperoleh dari boothstraping dengan melihat besarnya path coefficient. Hasil pengujian menunjukkan bahwa terdapat pengaruh yang postitif dan signifikan antara compatibility, visibility, image, result demonstrability, dan voluntariness, masing-masing terhadap perceived usefulness pada wearable technology. Perceived ease of use terbukti tidak berpengaruh terhadap perceived usefulness pada wearable technology. Sedangkan perceived ease of use dan perceived usefulness terbukti memiliki pengaruh yang postitif dan signifikan terhadap niat untuk mengadopsi wearable technology. Pengaruh tidak langsung variabel compatibility, image, result demonstrability, visibility, dan voluntariness terhadap adoption intention ditunjukkan oleh nilai t lebih besar dari 1,96 yang berarti variabel-variabel eksogen tersebut berpengaruh secara signifikan terhadap adoption intention melalui mediasi perceived usefulness. Pengaruh tidak langsung variabel perceived ease of use terhadap adoption intention melalui perceived usefulness ditunjukkan oleh nilai t kurang dari 1,96 yang berarti variabel perceived ease of use tidak memiliki pengaruh tidak langsung terhadap adoption intention.

Pengujian moderasi multi-group, seperti disajikan pada Tabel 2, digunakan untuk melihat perbandingan pengaruh moderasi jenis kelamin terhadap hubungan antar variabel. Oleh karena dikatakan signifikan memoderasi jika p-value < tingkat significant alpha yaitu 5\% atau 0,05 , maka hasil ini menunjukkan bahwa jenis kelamin tidak memoderasi secara signifikan pengaruh perceived ease of use dan perceived usefulness terhadap adoption intention. Hasil pengujian multi-group analysis menunjukkan bahwa jenis kelamin laki-laki dan perempuan tidak berbeda dalam memoderasi pengaruh perceived ease of use dan perceived usefulness terhadap adoption intention. Dengan kata lain, perbedaan jenis kelamin konsumen tidak mempengaruhi niat konsumen untuk menggunakan wearable technology.

Tabel 2. Perbandingan Moderating Effect Jenis Kelamin pada Adoption Intention

\begin{tabular}{|l|c|c|c|}
\hline Multi-Group Analysis & Path Coefficients-diff & p-Value & Keterangan \\
\hline ease of use -> adoption intention & 0,024 & 0,573 & $\begin{array}{c}\text { Tidak signifikan } \\
\text { memoderasi }\end{array}$ \\
\hline $\begin{array}{l}\text { perceived usefulness -> adoption } \\
\text { intention }\end{array}$ & 0,039 & 0,374 & $\begin{array}{c}\text { Tidak signifikan } \\
\text { memoderasi }\end{array}$ \\
\hline
\end{tabular}

(referensi: data diolah) 
Compatibility berpengaruh signifikan terhadap perceived usefulness pada wearable technology. Variabel compatibility dalam penelitian ini diukur dari kesesuaian wearable technology dengan aktivitas atau pekerjaan; kecocokan wearable technology dengan situasi atau rutinitas sehari-hari; dan kecocokan wearable technology dengan cara dan gaya bekerja. Hasil ini dapat diartikan bahwa responden menilai wearable technology sesuai dengan kebutuhan saat ini maupun pengalaman masa lalu. Sehingga, menggunakan wearable technology dinilai mampu membantu menyelesaikan hal-hal yang diperlukan untuk menjadi lebih produktif, mendukung dan membantu melakukan hal-hal penting dengan efektif, meningkatkan kemampuan dan mempermudah dalam beraktivitas ataupun menyelesaikan pekerjaan. Hal ini sesuai dengan hasil dari penelitian yang dilakukan oleh Hubert et al. (2019), Wang \& Lin (2016), dan Chau \& Hu (2001; dalam Lee et al. 2011). Semakin tinggi compatibility, semakin tinggi tingkat perceived usefulness. Dengan kata lain, semakin masyarakat menilai wearable technology memiliki kesesuaian dan konsistensi dengan kebutuhan dan gaya bekerja, maka semakin masyarakat percaya bahwa menggunakan wearable technology akan meningkatkan produktivitas dalam pekerjaan maupun dalam aktivitas sehari-hari.

Visibility berpengaruh signifikan terhadap perceived usefulness pada wearable technology. Variabel visibility dalam penelitian ini diukur dari kemudahan atau intensitas dalam melihat dan mengamati orang lain menggunakan wearable technology; dan banyaknya teman maupun orang di luar lingkungan terdekat yang menggunakan wearable technology. Hasil ini dapat diartikan bahwa responden dapat dengan mudah melihat orang lain menggunakan wearable technology. Sehingga, menggunakan wearable technology dinilai mampu membantu menyelesaikan hal-hal yang diperlukan untuk menjadi lebih produktif, mendukung dan membantu melakukan hal-hal penting dengan efektif, meningkatkan kemampuan dan mempermudah dalam beraktivitas ataupun menyelesaikan pekerjaan. Hal ini sesuai dengan hasil dari penelitian yang dilakukan oleh Huang (2004), dan Yang (2007; dalam Lee et al. 2011). Semakin tinggi visibility, semakin tinggi tingkat perceived usefulness. Dengan kata lain, semakin penggunaan wearable technology dapat dengan mudah dilihat dan diamati, maka semakin masyarakat percaya bahwa menggunakan wearable technology akan meningkatkan produktivitas dalam pekerjaan maupun dalam aktivitas sehari-hari.

Image berpengaruh signifikan terhadap perceived usefulness pada wearable technology. Variabel image dalam penelitian ini diukur dari peningkatkan profil, citra diri, dan prestige di tengah lingkungan; perasaan lebih dihargai oleh orang lain; dan wearable technology sebagai simbol status. Hasil ini dapat diartikan bahwa responden menganggap penggunaan wearable technology meningkatkan citra atau status seseorang dalam sistem sosial. Sehingga, menggunakan wearable technology dinilai mampu membantu menyelesaikan hal-hal yang diperlukan untuk menjadi lebih produktif, mendukung dan membantu melakukan hal-hal penting dengan efektif, meningkatkan kemampuan dan mempermudah dalam beraktivitas ataupun menyelesaikan pekerjaan. Hal ini sesuai dengan hasil dari penelitian yang dilakukan oleh Venkatesh \& Davis (2000). Semakin tinggi image, semakin tinggi tingkat perceived usefulness. Dengan kata lain, semakin penggunaan wearable technology dianggap meningkatkan citra atau status seseorang dalam sistem sosial, maka semakin masyarakat percaya bahwa menggunakan wearable technology akan meningkatkan produktivitas dalam pekerjaan maupun dalam aktivitas sehari-hari.

Result demonstrability berpengaruh signifikan terhadap perceived usefulness pada wearable technology. Variabel result demonstrability dalam penelitian ini diukur dari kejelasan hasil dalam menggunakan wearable technology; serta kemudahan mengkomunikasikan kepada orang lain tentang hasil dan konsekuensi menggunakan wearable technology. Hasil ini dapat 
diartikan bahwa responden menganggap hasil dari penggunaan wearable technology dapat terlihat dan mudah dikomunikasi kepada orang lain. Sehingga, menggunakan wearable technology dinilai mampu membantu menyelesaikan hal-hal yang diperlukan untuk menjadi lebih produktif, mendukung dan membantu melakukan hal-hal penting dengan efektif, meningkatkan kemampuan dan mempermudah dalam beraktivitas ataupun menyelesaikan pekerjaan. Hal ini sesuai dengan hasil dari penelitian yang dilakukan oleh Venkatesh \& Davis (2000) dan Hubert et al. (2019). Semakin tinggi result demonstrability, semakin tinggi tingkat perceived usefulness. Dengan kata lain, semakin hasil dari menggunakan wearable technology dapat terlihat dan dikomunikasikan kepada orang lain dengan mudah, maka semakin masyarakat percaya bahwa menggunakan wearable technology akan meningkatkan produktivitas dalam pekerjaan maupun dalam aktivitas sehari-hari.

Voluntariness berpengaruh signifikan terhadap perceived usefulness pada wearable technology. Variabel voluntariness dalam penelitian ini diukur dari ada atau tidaknya tuntutan, keharusan maupun kewajiban dari atasan untuk menggunakan wearable technology; serta adanya kebebasan atau kesukarelaan dalam menggunakan wearable technology. Hasil ini dapat diartikan bahwa responden menganggap penggunaan wearable technology bersifat sukarela dan tanpa paksaan. Sehingga, menggunakan wearable technology dinilai mampu membantu menyelesaikan hal-hal yang diperlukan untuk menjadi lebih produktif, mendukung dan membantu melakukan hal-hal penting dengan efektif, meningkatkan kemampuan dan mempermudah dalam beraktivitas ataupun menyelesaikan pekerjaan. Hal ini sesuai dengan hasil dari penelitian yang dilakukan oleh Venkatesh \& Davis (2000) dan Venkatesh et al. (2008; dalam Hassani et al. 2017). Semakin tinggi voluntariness, semakin tinggi tingkat perceived usefulness. Dengan kata lain, semakin penggunaan wearable technology dianggap sukarela atau melalui kehendak bebas seseorang, maka semakin masyarakat percaya bahwa menggunakan wearable technology akan meningkatkan produktivitas dalam pekerjaan maupun dalam aktivitas sehari-hari.

Perceived ease of use tidak terbukti mempengaruhi perceived usefulness pada wearable technology. Variabel perceived ease of use dalam penelitian ini diukur dari kemudahan dalam menggunakan dan mengoperasikan wearable technology. Hasil ini dapat diartikan bahwa walaupun wearable technology dianggap mudah untuk digunakan, responden tidak menilai wearable technology akan meningkatkan produktivitas dalam pekerjaan maupun dalam aktivitas sehari-hari. Hal ini tidak sesuai dengan hasil dari banyak penelitian terdahulu, salah satunya oleh Venkatesh \& Davis (2000). Variasi perubahan yang terjadi pada variabel perceived ease of use tidak diikuti perubahan pada variabel perceived usefulness terhadap wearable technology. Tingkat kesulitan atau kemudahan dalam menggunakan wearable technology tidak mempengaruhi persepsi masyarakat tentang peningkatkan produktivitas dalam pekerjaan maupun dalam aktivitas sehari-hari akibat dari menggunakan wearable technology. Di sisi lain, perceived ease of use terbukti berpengaruh signifikan terhadap adoption intention pada wearable technology. Hasil ini dapat diartikan bahwa responden menganggap wearable technology mudah untuk digunakan, sehingga muncul dorongan untuk menggunakan wearable technology. Hal ini sesuai dengan hasil dari penelitian yang dilakukan oleh Davis (1989) dan Venkatesh (1999; dalam Venkatesh \& Davis 2000). Semakin tinggi perceived ease of use, semakin tinggi tingkat adoption intention. Dengan kata lain, semakin wearable technology dianggap mudah untuk digunakan, maka akan semakin tinggi niat seseorang untuk mengadopsi wearable technology.

Perceived usefulness berpengaruh signifikan terhadap adoption intention pada wearable technology. Hasil ini dapat diartikan bahwa responden menilai penggunaan wearable technology mampu membantu menyelesaikan hal-hal yang diperlukan untuk menjadi lebih produktif, mendukung dan membantu melakukan hal-hal penting dengan efektif, 
meningkatkan kemampuan dan mempermudah dalam beraktivitas ataupun menyelesaikan pekerjaan. Sehingga, muncul dorongan untuk menggunakan wearable technology. Hal ini sesuai dengan hasil dari penelitian yang dilakukan oleh Lee et al. (2003) yang melakukan metaanalysis dan menemukan 74 penelitian terdahulu yang menunjukan pengaruh yang signifikan dari perceived usefulness terhadap adoption intention. Semakin tinggi perceived usefulness, semakin tinggi tingkat adoption intention. Dengan kata lain, semakin masyarakat percaya bahwa menggunakan wearable technology akan meningkatkan produktivitas dalam pekerjaan maupun dalam aktivitas sehari-hari, maka akan semakin tinggi niat seseorang untuk mengadopsi wearable technology.

Compatibility, visibility, image, result demonstrability, dan voluntariness berpengaruh secara tidak langsung terhadap adoption intention pada wearable technology melalu mediasi perceived usefulness. Perceived usefulness adalah faktor kuat yang mampu memediasi pengaruh variabel-variabel IDT terhadap terbentuknya niat seseorang untuk mengadopsi wearable technology. Dengan kata lain dapat diartikan bahwa compatibility, visibility, image, result demonstrability, dan voluntariness adalah faktor-faktor yang terbukti membentuk perceived usefulness dari wearable technology, yang kemudian mempengaruhi niat seseorang untuk mengadopsi teknologi tersebut.

\section{Kesimpulan}

Hasil analisis menunjukkan bahwa compatibility berpengaruh signifikan terhadap perceived usefulness pada wearable technology. Semakin masyarakat menilai wearable technology memiliki kesesuaian dan konsistensi dengan kebutuhan dan gaya bekerja, maka semakin masyarakat percaya bahwa menggunakan wearable technology akan meningkatkan produktivitas dalam pekerjaan maupun dalam aktivitas sehari-hari. Visibility berpengaruh signifikan terhadap perceived usefulness pada wearable technology. Semakin penggunaan wearable technology dapat dengan mudah dilihat dan diamati, maka semakin masyarakat percaya bahwa menggunakan wearable technology akan meningkatkan produktivitas dalam pekerjaan maupun dalam aktivitas sehari-hari. Image berpengaruh signifikan terhadap perceived usefulness pada wearable technology. Semakin penggunaan wearable technology dianggap meningkatkan citra atau status seseorang dalam sistem sosial, maka semakin masyarakat percaya bahwa menggunakan wearable technology akan meningkatkan produktivitas dalam pekerjaan maupun dalam aktivitas sehari-hari. Result demonstrability berpengaruh signifikan terhadap perceived usefulness pada wearable technology. Semakin hasil dari menggunakan wearable technology dapat terlihat dan dikomunikasikan kepada orang lain dengan mudah, maka semakin masyarakat percaya bahwa menggunakan wearable technology akan meningkatkan produktivitas dalam pekerjaan maupun dalam aktivitas seharihari. Voluntariness berpengaruh signifikan terhadap perceived usefulness pada wearable technology. Semakin penggunaan wearable technology dianggap sukarela atau melalui kehendak bebas seseorang, maka semakin masyarakat percaya bahwa menggunakan wearable technology akan meningkatkan produktivitas dalam pekerjaan maupun dalam aktivitas seharihari.

Perceived ease of use tidak terbukti berpengaruh terhadap perceived usefulness pada wearable technology. Tingkat kesulitan atau kemudahan dalam menggunakan wearable technology tidak mempengaruhi persepsi masyarakat tentang peningkatkan produktivitas dalam pekerjaan maupun dalam aktivitas sehari-hari akibat menggunakan wearable technology. Di sisi lain, perceived ease of use terbukti berpengaruh signifikan terhadap adoption intention pada wearable technology. Semakin wearable technology dianggap mudah untuk digunakan, maka akan semakin tinggi niat seseorang untuk mengadopsi wearable 
technology. Perceived usefulness juga berpengaruh signifikan terhadap adoption intention pada wearable technology. Semakin masyarakat percaya bahwa menggunakan wearable technology akan meningkatkan produktivitas dalam pekerjaan maupun dalam aktivitas sehari-hari, maka akan semakin tinggi niat seseorang untuk mengadopsi wearable technology.

Pengujian indirect effect menujukkan bahwa perceived usefulness dari wearable technology adalah faktor kuat yang mampu memediasi pengaruh compatibility, visibility, image, result demonstrability, dan voluntariness terhadap terbentuknya niat seseorang untuk mengadopsi wearable technology. Hal ini mengarah pada kesimpulan bahwa compatibility, visibility, image, result demonstrability, dan voluntariness adalah faktor-faktor yang terbukti membentuk perceived usefulness dari wearable technology, yang kemudian mempengaruhi niat seseorang untuk mengadopsi teknologi tersebut. Sedangkan perceived ease of use mempengaruhi secara langsung niat seseorang untuk mengadopsi teknologi tersebut. Informasi ini penting dan relevan bagi para pengembang dan peritel produk wearable technology.

Pengujian multi-group analysis menunjukkan bahwa jenis kelamin laki-laki dan perempuan tidak memoderasi pengaruh perceived ease of use dan perceived usefulness terhadap adoption intention. Maka dapat diartikan bahwa perbedaan jenis kelamin tidak mempengaruhi niat konsumen untuk menggunakan wearable technology.

\section{Daftar Pustaka}

Agarwal, R., \& Prasad, J. (1997). The Role of Innovation Characteristics and Perceived Voluntariness in the Acceptance of Information Technologies. Decision Sciences, 28(3), $557-582$.

Ajzen, I. (1991). The Theory of Planned Behaviour. Organizational Behaviour and Human Decision Process, 50(2), 179-211.

Benham, H., \& Raymond, B. (1996). Information Technology Adoption: Evidence from a Voice Mail Introduction. Computer Personnel, 17(1), 3-25.

Davis, F. D. (1986). A Technology Acceptance Model For Empirically Testing New End-User Information Systems: Theory And Results. Doctoral Dissertation, Massachusetts Institute of Technology Sloan School of Management Cambridge.

Davis, F. D. (1989). Perceived Usefulness, Perceived Ease of Use, and User Acceptance of Information Technology. MIS Quarterly, 13(3), 319-340.

Fishbein, M., \& Ajzen, I. (1975). Belief, Attitude, Intention and Behavior: an Introduction to Theory and Research. Addison-Wesley.

Ghozali, I., \& Latan, H. (2015). Partial Least Squares Konsep Teknik dan Aplikasi Menggunakan Program SmartPLS 3.0 (2nd ed.). Badan Penerbit Universitas Diponegoro.

Grand View Research. (2020). Wearable Technology Market Size, Share \& Trends Analysis Report By Product (Wrist-wear, Eye-wear \& Head-wear, Foot-wear, Neck-wear, Bodywear), By Application, By Region, And Segment Forecasts. https://www.grandviewresearch.com/industry-analysis/wearable-technology-market

Hair, J. J. F., Black, W. C., Babin, B. J., \& Anderson, R. E. (2014). Multivariate Data Analysis (7th ed.). Pearson Education Limited.

Hassani, I. B., Chroqui, R., Okar, C., Talea, M., \& Ouiddad, A. (2017). Literature review : All about IDT and TAM. Literature Review: All about IDT and TAM.

Hubert, M., Blut, M., Brock, C., Zhang, R. W., Koch, V., \& Riedl, R. (2019). The Influence of Acceptance and Adoption Drivers on Smart Home Usage. European Journal of Marketing, 53(6), 1073-1098.

Lee, Y.-H., Hsieh, Y.-C., \& Hsu, C.-N. (2011). Adding Innovation Diffusion Theory to the 
Technology Acceptance Model: Supporting Employees' Intentions to use E-Learning Systems. Educational Technology \& Society, 14(4), 124-137.

Lee, Y., Kozar, K. A., \& Larsen, K. R. T. (2003). The Technology Acceptance Model: Past, Present, and Future. Communications of the Association for Information Systems, 12(1), 752-780.

Liu, X., Vega, K., Maes, P., \& Paradiso, J. A. (2016). Wearability Factors for Skin Interfaces. Proceedings of the 7th Augmented Human International Conference, 1-8.

Moore, G. C., \& Benbasat, I. (1991). Development of an Instrument to Measure the Perceptions of Adopting an Information Technology Innovation. The Institute of Management Sciences, 2(3), 192-222.

Mutahar, A. M., Daud, N. M., Ramayah, T., Isaac, O., \& Alrajawy, I. (2017). Integration of Innovation Diffusion Theory and Technology Acceptance Model to Understand Mobile Banking Acceptance in Yemen: The Moderating Effect of Income. International Journal of Soft Computing, 12(3), 164-177.

Nunes, G. S., \& Filho, E. J. M. A. (2018). Consumer behavior regarding wearable technologies: Google Glass. Innovation \& Management Review, 15(3), 230-246.

Park, Y. J., \& Skoric, M. (2017). Personalized Ad in Your Google Glass? Wearable Technology, Hands-Off Data Collection, and New Policy Imperative. Journal Business Ethics, 142, 71-82.

Pricewaterhouse Coopers. (2014). The Wearable Future. Consumer Intelligence Series. https://www.pwc.se/sv/pdf-reports/consumer-intelligence-series-the-wearable-future.pdf

Rogers, E. M. (1983). Diffusion of Innovations (3rd ed.). The Free Press.

Rogers, E. M. (2003). Diffusion of Innovations (5th ed.). The Free Press.

Venkatesh, V., \& Davis, F. D. (2000). A Theoretical Extension of the Technology Acceptance Model: Four Longitudinal Field Studies. Management Science, 46(2), 186-204.

Wang, Y.-M., \& Lin, Y.-S. (2016). Determinants of Internet Entrepreneurship Intentions among Business School Students. International Journal of Information and Education Technology, 6(10), 754-758.

Wani, T. A., \& Ali, S. W. (2015). Innovation Diffusion Theory: Review \& Scope in the Study Of Adoption Of Smartphones In India. Journal Of General Management Research, 3(2), 101-118. 